\title{
Comparative Study on the Effect of Support for Nanonickel Catalyst in Reduction of Nitrophenols
}

\author{
Haiam H. Ibraheem, Doaa M. El-Mekkawi" , S. A. Hassan ${ }^{* *}$ \\ and M. M. Selim ${ }^{* \#}$ \\ Ministry of Scientific Research, *Physical Chemistry Dept. \\ National Research Center and **Faculty of Science, Ain \\ Shams University, Cairo, Egypt.
}

\begin{abstract}
7 HE CATALYTIC reduction of para- and ortho- nitrophenols to the corresponding aminophenols was investigated over $\mathrm{Ni} / \mathrm{TiO}_{2}$ catalysts prepared by reduction method. Hydrazine hydrate in the presence of nickel ions supported on $\mathrm{TiO}_{2}$ was used in the preparation of nanonickel catalyst over rutile and anatase. Further decomposition of the hydrazine hydrate on the nickel atoms surfaces yields nascent hydrogen atoms that efficiently reduce the nitro groups. Many techniques such as XRD, IR, TEM and UV-Visible absorption spectroscopy have been used. TEM shows the formation of nanonickel clusters on $\mathrm{TiO}_{2}$. IR analysis confirms the appearance of the characteristic peaks of only ortho or para aminophenols. The kinetics of reduction reaction was studied. Catalyst recovery and factors affecting the reduction reaction such as phenol concentration, $\mathrm{pH}$, catalyst loading and temperature have been studied. The obtained data and kinetic results show that the conversion percentage reaches $100 \%$ within few minutes. The results indicate that the nanonickel loaded over rutile or anatase $\mathrm{TiO}_{2}$ exhibit nearly the same catalytic activity in reduction of nitrophenols but more active than nanonickel in zeolite catalyst.
\end{abstract}

Keywords: Nickel nanocatalyst, Rutile, Anatase, Nitrophenols, Aminophenols and Reduction.

Nitrophenols are among the most common organic pollutants in industrial and agricultural wastewaters. Many processes have been developed for their removal such as adsorption ${ }^{(1)}$, microbial degradation ${ }^{(2)}$, photocatalytic degradation $^{(3)}$, microwave-assisted catalytic oxidation ${ }^{(4)}$, electro-Fenton method ${ }^{(5)}$, electrocoagulation $^{(6)}$, electrochemical treatment ${ }^{(7)}$ and so on. On the other hand, 4aminophenol (4-AP) is an important intermediate for the manufacture of analgesic and antipyretic drugs. They can be synthesized by the catalytic hydrogenation of 4-nitrophenol (4-NP) in ethanol at relatively high temperature and high hydrogen pressure ${ }^{(8-10)}$.

Raney nickel ${ }^{(11)}$, nano-sized nickel ${ }^{(12)}$ and several noble metal catalysts such as $\mathrm{Pd} / \mathrm{C}^{(13)}$ have been used as catalysts for reduction reaction of nitrophenols. Due to cheaper price and higher catalytic activity, supported nickel catalysts are

\#Corresponding author: E-mail-mmaselim@yahoo.com 
widely used in various reactions ${ }^{(14-20)}$. Moreover, compared to unsupported nanosized nickel catalysts, supported nickel catalysts are easy to recover in a slurry reactor. There are few reports on the catalytic reduction of p-nitrophenol over supported nickel catalysts.

Titania has attracted much interest as a support material for metals or metal oxides due to its ability to modify the catalytic properties of the supported phase $^{(21-22)}$. It is known that titania exists in three main structures: anatase, rutile, and brookite, and each structure shows different physical properties. It is inferred that metal supported on titania with different structures might exhibit different physio-chemical properties and catalytic properties. However, little on such difference has been reported ${ }^{(23,24)}$.

The reduction of aromatic nitro compounds with hydrazine or hydrazine hydrate represents a special variation of the catalytic reduction, where hydrazine is the source of the hydrogen. The hydrogen can be generated by a variety of $\mathrm{H}$ transfer catalysts. Especially with the use of noble metal catalysts, such as Pd, Pt or $\mathrm{Ru}$, but also with the application of $\mathrm{Ni}$ or $\mathrm{Cu}$, the catalytic hydrazine reduction gives high yields comparable to or better than the catalytic hydrogenation ${ }^{(25)}$. In a previous work, the catalytic activity of nanonickel supported zeolite on the reduction of nitrophenols was studied ${ }^{(26)}$. Moreover, the use of $\mathrm{TiO}_{2}$ (anatase) as a support for nanonickel catalyst was investigated, and it was found that the catalyst exhibited activity more than Raney nickel ${ }^{(27)}$. In this work, the effects of titania structure (rutile and anatase) on the rate of reduction reaction of $\mathrm{o}$ - and $\mathrm{p}$ nitrophenols to o- and p-aminophenols have been investigated. The catalytic reduction over $\mathrm{Ni} / \mathrm{TiO}_{2}$ catalysts in presence of hydrazine hydrate as a reducing agent in mild conditions has been performed. The conversion percentage as well as catalyst recovery using $\mathrm{Ni} / \mathrm{TiO}_{2}$ catalysts are conducted. Factors affecting the reduction processes such as (concentration, $\mathrm{pH}$, temperature and catalyst loading) are also studied and discussed in details.

\section{Experimental}

\section{Materials}

The following materials were used in the investigation: $\mathrm{Ni}\left(\mathrm{NO}_{3}\right)_{2} \cdot 6 \mathrm{H}_{2} \mathrm{O}$ (purity 98\%, Lab Rasayan), p- $\mathrm{NO}_{2}$ phenol (purity 98\%, Oxford Lab Rasayan, Mombay- India), o- $\mathrm{NO}_{2}$ phenol (purity 99\%, BDH, England), $\mathrm{p}-\mathrm{NH}_{2}$ phenol (purity 96\%, pract), o- $\mathrm{NH}_{2}$ phenol (purity 96\%, pract), hydrazine hydrated $\left(\mathrm{H}_{6} \mathrm{~N}_{2} \mathrm{O}\right)$ (purity $99-100 \%$, Laboratory Rasayan rankem), sodium hydroxide (purity 97\% min, spectrum chemical mfg. corp.), ethyl alcohol (purity 99.8\% analar, alpha chemika).

\section{Impregnation method}

The present work describes a simple procedure for the preparation of $\mathrm{Ni} / \mathrm{TiO}_{2}$ (rutile or anatase) using the wet impregnation method. $5 \% \mathrm{Ni} / \mathrm{TiO}_{2}$ was prepared by the impregnation method. As $5 \mathrm{~g}$ of $\mathrm{TiO}_{2}$ in rutile or anatase form was 
impregnated with a solution composed of a definite weight of $\mathrm{Ni}\left(\mathrm{NO}_{3}\right)_{2} \cdot 6 \mathrm{H}_{2} \mathrm{O}$ dissolved in the least amount of distilled water.

\section{Reduction of nitrophenols}

$0.1 \mathrm{~g}$ of $\mathrm{Ni} / \mathrm{TiO}_{2}$ was mixed with $15 \mathrm{ml}$ of hydrazine hydrate and $5 \mathrm{ml}$ of $\mathrm{NaOH}(10 \%)$ and heated at $70^{\circ} \mathrm{C}$. Within few minutes, a black color appeared indicating the reduction of nickel ions into atoms.

To the formed $\mathrm{N} / \mathrm{TiO}_{2}$ catalyst $0.5 \mathrm{~g}$ of nitrophenol in ethanol was added. Again $10 \mathrm{ml}$ of hydrazine hydrate along with a quantity of $\mathrm{NaOH}$ solution were added to help the reduction of nitrophenols into the corresponding aminophenols. The initial reaction volume was kept constant at $100 \mathrm{ml}$ using ethanol.

The total conversion of nitrophenols was calculated using the following equation:

$$
\% \text { Conversion }=\left(\mathrm{A}_{0}-\mathrm{A}\right) / \mathrm{A}_{0} \times 100
$$

where $A_{0}$ and $A$ are the absorbance values of nitrophenol at a given wavelength $(\mathrm{nm})$ at 0 time and definite time, respectively.

\section{TEM measurements}

The tested samples of $\mathrm{Ni} / \mathrm{TiO}_{2}$ by means of the transmission electron microscope (TEM) were prepared by dispersing these samples in distilled water followed by ultrasonic vibration for half an hour. A drop of the dispersed sample was placed onto a copper grid coated with a layer of amorphous carbon. A Jeol Transmission Electron Microscope, jel 1230, RV $120 \mathrm{KV}$ was used to study the shape and size of the sample.

Infrared spectral analysis

IR spectra were collected on Perkin Elmer 1000 with a resolution of 4. This technique was used to investigate quantized molecular resonance that absorbs electromagnetic energy selectively from a broad band infrared source, where $1 \mathrm{mg}$ of the fine sample powder was of the nitro and / or amino phenol mixed with $\sim 200 \mathrm{mg} \mathrm{KBr}$. The mixture was then pressed to form a more or less transparent disk and then scanned in the range of 2000 to $400 \mathrm{~cm}^{-1}$.

$U V$-Visible measurements

UV-Visible absorption measurements were obtained using a UV 2401PC record spectrometer, Shimadzu.

\section{Results and Discussion}

\section{Characterization of the catalyst}

Hydrazine hydrate in the presence of nickel ions supported on $\mathrm{TiO}_{2}$ was used in the preparation of nanonickel catalyst over rutile and anatase. $\mathrm{Ni}$ ions supported on $\mathrm{TiO}_{2}$ are transferred into metallic nickel after reduction with 
hydrazine hydrate in presence of $\mathrm{NaOH}$ at $\mathrm{pH}$ 9. TEM micrograph of $\mathrm{Ni} / \mathrm{TiO}_{2}(\mathrm{R})$ in Fig. 1 indicates that the nickel clusters (dark field) are uniformly dispersed on the surface of rutile titania support and the average size of $\mathrm{Ni}$ cluster is about $25 \mathrm{~nm}$.

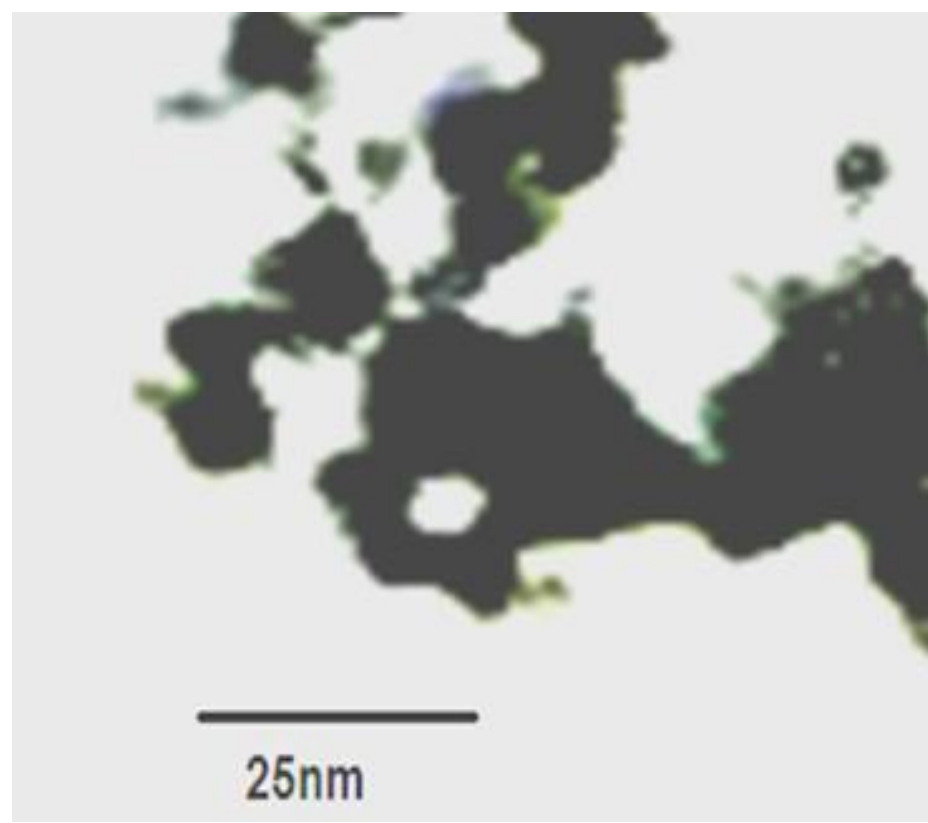

Fig. 1.TEM image of $\mathrm{Ni} / \mathrm{TiO}_{2}(\mathrm{R})$.

Reduction of nitrophenols (preliminary studies)

$U V$-Visible measurements

$\mathrm{UV}-\mathrm{V}$ is technique was used in studying the reduction reaction of nitrophenols into the corresponding aminophenols. P-nitrophenol shows maximum absorbance in the visible region at wavelength $400 \mathrm{~nm}$, whereas the maximum absorbance of pure p-aminophenol is in the UV region at $300 \mathrm{~nm}$. The absorbance values at these wavelengths are quite suitable to follow up the reduction of p-nitrophenol to the corresponding aminophenol. Since no interference is observed between both compounds (Fig. 3). The same was found for o-nitrophenol and o-aminophenol where the absorbance at wavelengths 415 $\mathrm{nm}$ and $286 \mathrm{~nm}$ were taken to follow up the reduction of o-nitrophenol into oaminophenol, respectively. Starting the reduction reaction, the characteristic peaks of nitrophenols at longer wavelenghts decrease and at complete reduction they completely disappear while the characteristic peaks for aminophenols at shorter wavelength increase, which is considered as an evidence for the reduction of nitro group into amino group (Fig. 2 and 3). 


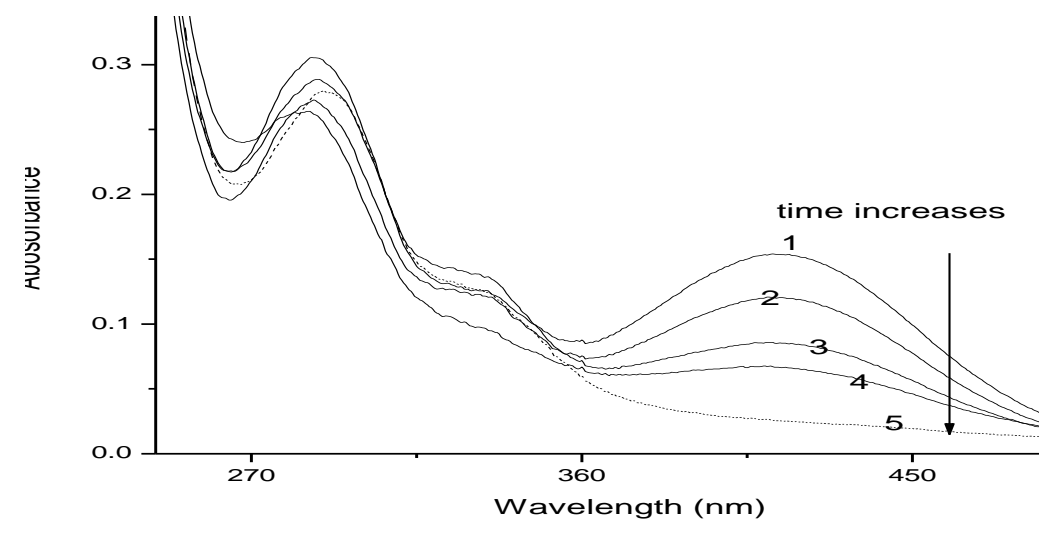

Fig. 2. UV-Visible absorption spectra of o-nitrophenol and different intervals of reduction reaction (pure o-nitrophenol: (1) and pure o-aminophenol: (5)).

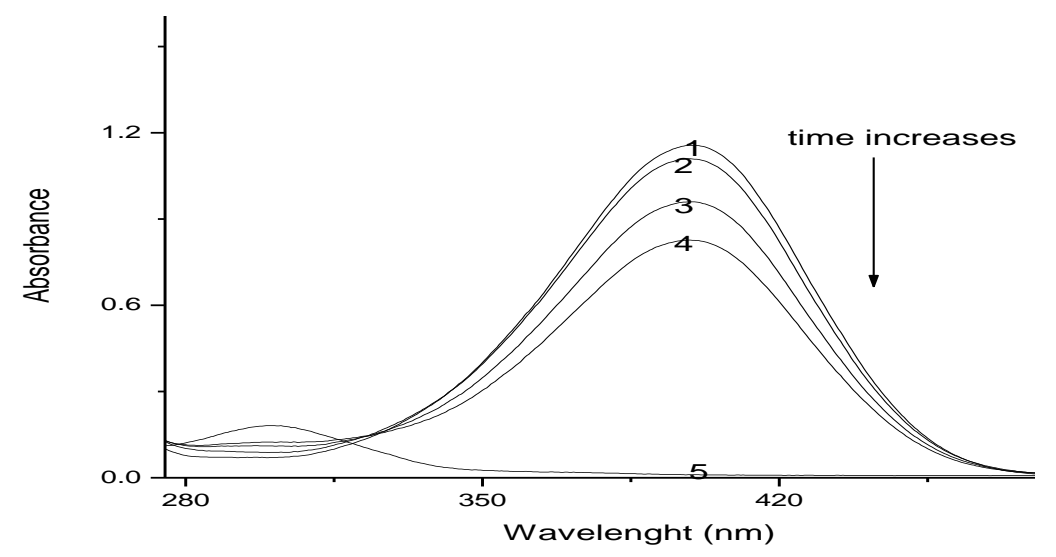

Fig. 3. UV-Visible absorption spectra of p-nitrophenol and different intervals of reduction reaction (pure p-nitrophenol: (1) and pure p-aminophenol: (5)).

\section{pH Effect}

The effect of $\mathrm{pH}$ on the reduction reaction of $\mathrm{o}$ - and $\mathrm{p}$ - nitrophenols has been studied. It was found that the $\mathrm{pH} 9$ is the most suitable one because the absorption spectra for nitrophenols did not interfere with that of $\mathrm{o}$ - and $\mathrm{p}$ aminophenol. These results can be seen in Fig. 4 and 5. Besides, preliminary studies on the effect of $\mathrm{pH}$ on the reduction of nitrophenols into the corresponding aminophenols were done. At low pH's less than 9 no reduction was observed, these observations lead us to adjust the medium at $\mathrm{pH} 9$ during the reduction processes. 


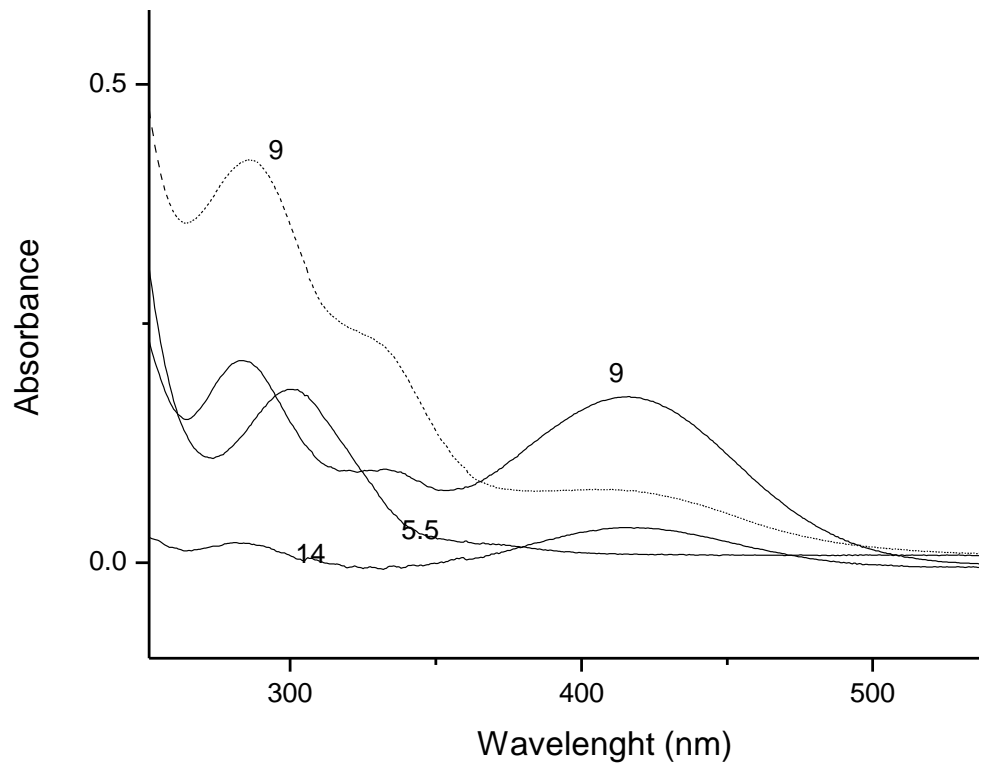

Fig. 4. UV/Visible absorption spectra of o-nitrophenol (solid lines) and o-aminophenol (dot line) at different $\mathrm{pH}(5.5,9$ and 14).

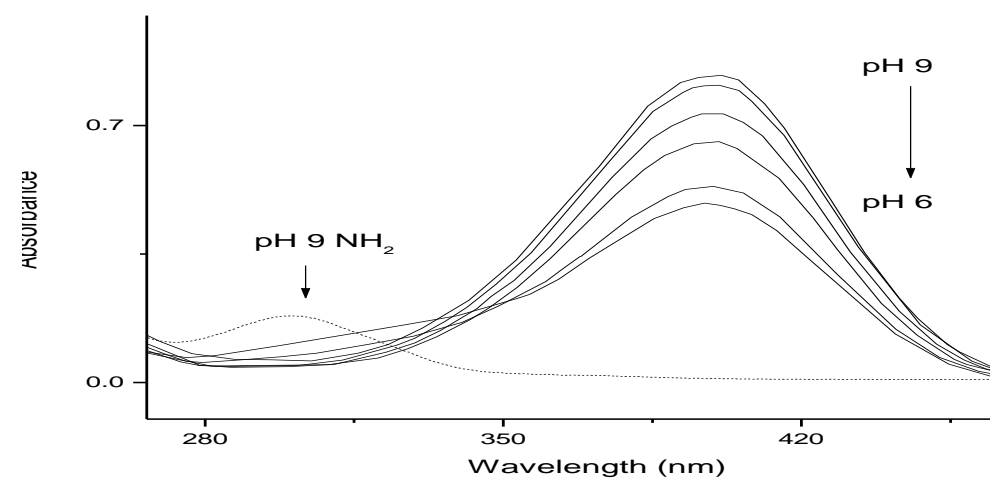

Fig. 5. UV/Visible absorption spectra of p-nitrophenol (solid lines) and paminophenol (dot line) at different pH (6-12).

\section{Products characterization}

After complete reduction reaction of the sample of nitrophenol, the products were extracted many times with methyl ethyl ketone in case of p-aminophenol and petroleum ether in case of o-aminophenol. The extracted solids after vaporization under vacuum were used for IR investigation. The results confirm the formation of the corresponding aminophenols. The obtained solids were weighed to ensure that the conversion is about $100 \%$. Moreover, the melting

Egypt. J. Chem. 54, No.1 (2011) 
point of these samples were performed and we found that the melting point was $190^{\circ} \mathrm{C}$ after complete reduction of p-nitrophenol (m.p. $114^{\circ} \mathrm{C}$ ) as the yellow colour of the sample disappeared and the reaction solution colour became colourless. The disappearance of orange colour of o-nitrophenol was an evidence of complete reduction ensured by measuring the melting point $170^{\circ} \mathrm{C}$ characterized to o-aminophenol (m.p. $45^{\circ} \mathrm{C}$ ) .

\section{Kinetics of the reduction reaction}

The kinetics of reduction reaction using $5 \% \mathrm{Ni}^{-\mathrm{TiO}_{2}}$ on anatase, rutile forms and Ni-Y zeolite catalyst was studied. The reduction reactions follow the first order kinetic analysis. Plotting $\ln \mathrm{A}$ versus time gives a linear relationship of a slope equals to the rate constant of the given reaction (Fig. 6 and 7). The rate constant values for the reduction reaction of $\mathrm{p}$ - and o-nitro phenols at different amounts of the catalyst are given in Table 1 . The data are compared to that obtained in a previous work using $\mathrm{Ni}$ supported zeolite keeping the amount of supported $\mathrm{Ni}$ constant in all experiments ${ }^{(26)}$. Inspection of Table 1 shows the following: (i) Nanonickel supported on $\mathrm{TiO}_{2}$ is more catalytically active than the nanonickel in zeolite. (ii) The rate constant of the reduction of p-nitrophenol is slightly higher than that of the o-nitrophenol in case of Ni-Y zeolite. (iii) The rate constant of the reduction of o-nitrophenol is slightly higher than that of the p-nitrophenol in case of $\mathrm{Ni}-\mathrm{TiO}_{2}$. (iv) Both rutile and anatase show comparable rate constant values for the reduction of $\mathrm{p}$ - and o- nitrophenols.

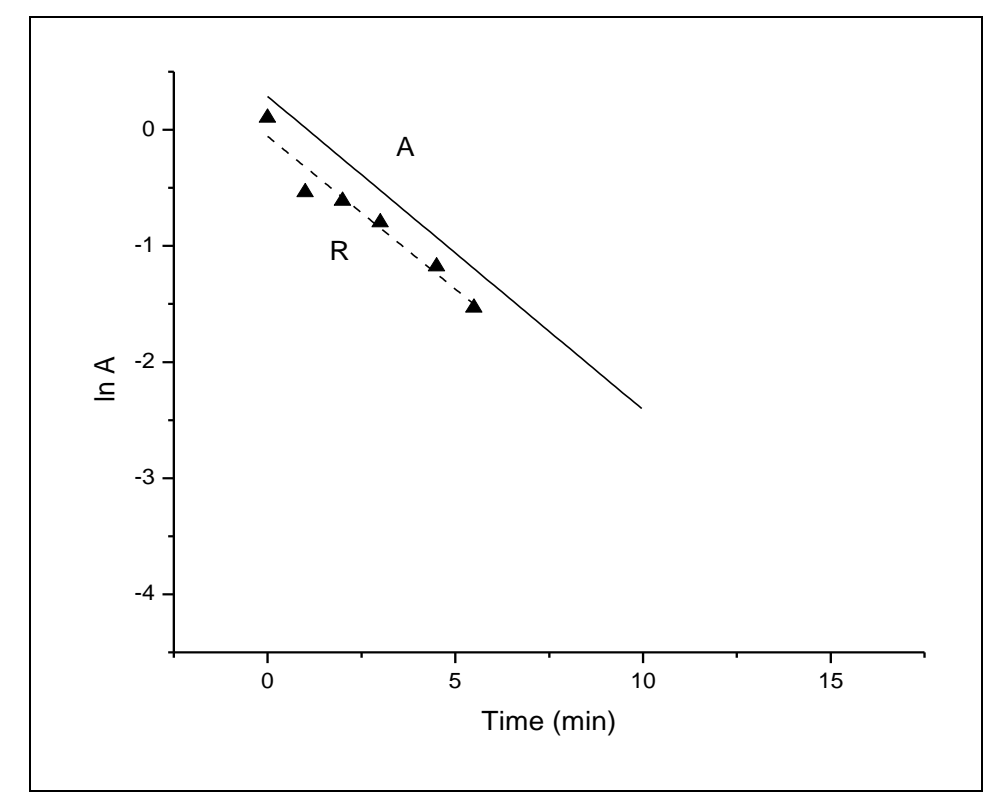

Fig. 6. First order kinetic analysis of the catalytic reduction of $(0.4 \mathrm{gm})$ of pnitrophenol using $0.1 \mathrm{gm} \mathrm{Ni} / \mathrm{TiO}_{2}$ (anatase and rutile) . 


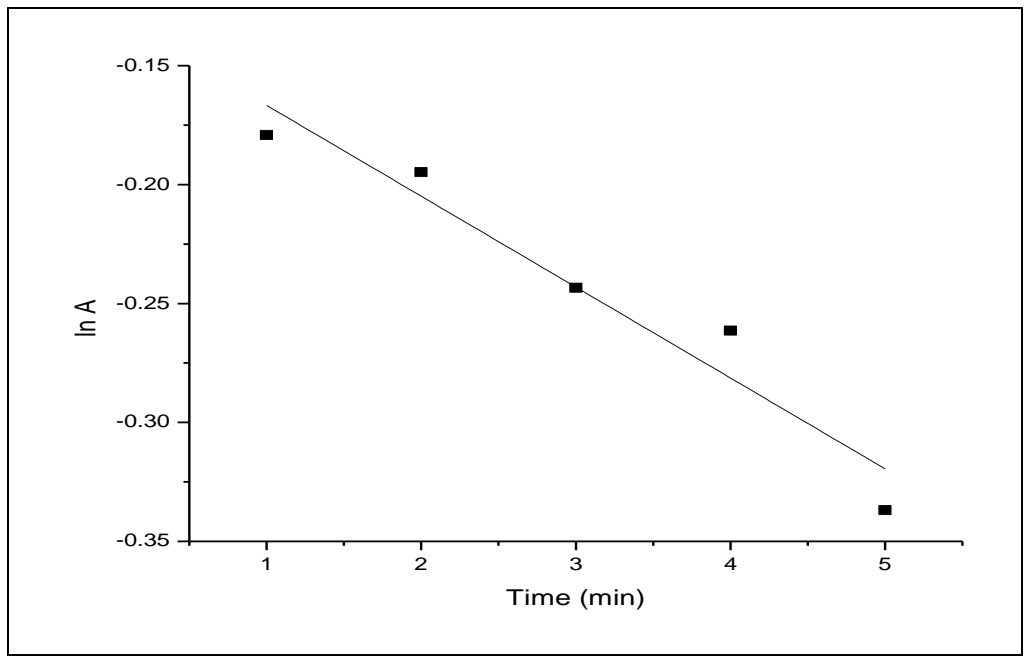

Fig. 7. First order kinetic analysis of the catalytic reduction of $(0.4 \mathrm{gm})$ of pnitrophenol using $0.1 \mathrm{gm} \mathrm{Ni-Y}$ zeolite.

TABLE 1. The kinetics of the reduction reaction of p- and o-nitrophenol using Ni$\mathrm{TiO}_{2}$ in anatase form, rutile form and $\mathrm{Ni}-\mathrm{Y}$ zeolite. (weight of nitrophenol $0.4 \mathrm{~g}$, temperature $=70^{\circ} \mathrm{C}$, volume of the solution $100 \mathrm{ml}$, and $\mathbf{p H}=9$ ).

\begin{tabular}{|c|c|c|c|}
\hline \multirow{2}{*}{ Catalyst } & \multirow{2}{*}{ Wt. of catalyst $(\mathbf{g})$} & \multicolumn{2}{|c|}{ Rate constant $\left(\mathbf{m i n}^{-\mathbf{1}}\right)$} \\
\cline { 3 - 4 } & & p-nitrophenol & o-nitrophenol \\
\hline $\mathbf{5 \%} \mathbf{~ N i - T i O} \mathbf{2}(\mathbf{R})$ & 0.15 & 0.20 & 0.29 \\
\hline $\mathbf{5 \%} \mathbf{~ N i - T i O} \mathbf{2}_{\mathbf{2}}(\mathbf{A})$ & 0.15 & 0.20 & 0.28 \\
\hline $\mathbf{2 . 5 \%} \mathbf{~ N i} \mathbf{Y}^{*}$ zeolite & 0.30 & 0.10 & 0.08 \\
\hline
\end{tabular}

$* 2.5 \% \mathrm{Ni}$ in zeolite is the maximum amount of exchanged nickel ions after which the structure of zeolite collapses (confirmed by XRD) ${ }^{(26)}$.

The above results can be explained on the light of the following: (i) The lower rate of the reduction reaction of nitrophenols using $\mathrm{Ni}-\mathrm{Y}$ zeolite than that of $\mathrm{Ni}-\mathrm{TiO}_{2}$ may be attributed to the open surface of $\mathrm{Ni}-\mathrm{TiO}_{2}$ that may facilitate the interaction between nickel atoms with both hydrazine and nitrophenols during the reduction reaction. (ii) The rate constant of the reduction of p-nitrophenol is slightly higher than that of the o-nitrophenol in case of Ni-Y zeolite. This can be due to the steric hindrance arising from the o-nitrophenol structure - in contrary to p-nitrophenol structure- which may cause difficulty for their entrance into zeolite cages. (iii) The rate constant of the reduction of onitrophenol is slightly higher than that of the p-nitrophenol in case of $\mathrm{Ni}-\mathrm{TiO}_{2}$. This may be explained in terms of the adsorption of o-nitrophenol on $\mathrm{TiO}_{2}$ surfaces through formation of surface complex between Ti(IV) and the adjacent hydroxyl and nitro groups. (iv) Both rutile and anatase show comparable rate

Egypt. J. Chem. 54, No.1 (2011) 
constant values for the reduction of $\mathrm{p}$ - and o- nitrophenols. This leads us to use the lower cost rutile $\mathrm{TiO}_{2}$ in the following experimental work.

\section{Optimization}

Several experiments were performed for studying the reduction reaction of onitrophenol and p-nitrophenol at different conditions to reach the optimum results.

\section{Temperature}

The reduction of o- and p-nitrophenols using $5 \% \mathrm{Ni}^{-\mathrm{TiO}_{2}}(\mathrm{R})$ was conducted at different temperatures $\left(60-80^{\circ} \mathrm{C}\right)$.

From Table 2 it can be observed that fixed time $(10 \mathrm{~min})$ at temperature lower than $70^{\circ} \mathrm{C}$ the conversion for both nitrophenols was very low and increasing the reaction time did not affect the conversion percentage. At $75^{\circ} \mathrm{C}$ the conversion of o- $\mathrm{NO}_{2}$ phenol was more than $84 \%$ while, $100 \%$ conversion was achieved at $80^{\circ} \mathrm{C}$ for both nitrophenols.

TABLE 2. The effect of temperature on the conversion of $p$ - and $\mathrm{o}-\mathrm{NO}_{2}$ phenol (weight of nitrophenol $0.4 \mathrm{~g}$, weight of catalyst $0.1 \mathrm{~g}$, volume of the solution $100 \mathrm{ml}, 10 \mathrm{~min}$ and $\mathrm{pH} \mathrm{9}$ ) .

\begin{tabular}{|c|c|c|}
\hline Temperature & $\begin{array}{c}\text { Conversion \% of } \\
\mathbf{p}^{-N_{2} \text { phenol }}\end{array}$ & $\begin{array}{c}\text { Conversion \% of } \\
\text { o-NO }\end{array}$ \\
\hline 60 & 19.8 & 47 \\
\hline 65 & 22.4 & 63.6 \\
\hline 70 & 31.3 & 75.2 \\
\hline 75 & 40 & 84 \\
\hline 80 & 100 & 100 \\
\hline
\end{tabular}

$\mathrm{Ni}$ - loading in $\mathrm{TiO}_{2}$

The data for the dependency of $\mathrm{p}$ - and o-nitrophenol conversion percentage on the amount of $\mathrm{Ni}$ loaded on $\mathrm{TiO}_{2}(\mathrm{R})$ surfaces is given in Table 3. It was noticed that $5 \% \mathrm{Ni}$ on $\mathrm{TiO}_{2}(\mathrm{R})$ support is the most favorable loading percentage for the reduction process for $\mathrm{o}$ - and $\mathrm{p}$ - nitrophenol at constant temperature, $\mathrm{pH}$ and volume.

TABLE 3. The effect of loading of $\mathrm{Ni}$ ions on the support (R) on the conversion of $\mathrm{p}$ and $\mathrm{o}-\mathrm{NO}_{2}$ phenol (weight of nitrophenol $0.4 \mathrm{~g}$, weight of catalyst $0.1 \mathrm{~g}$ volume of the solution $100 \mathrm{ml}, 7^{\circ} \mathrm{C}$ and $\mathrm{pH} \mathrm{9)}$.

\begin{tabular}{|c|c|c|}
\hline$\% \mathbf{N i} / \mathrm{TiO}_{\mathbf{2}}(\mathrm{R})$ & $\begin{array}{c}\text { Conversion \% of } \\
\text { p-NO }\end{array}$ & $\begin{array}{c}\text { Conversion \% of } \\
\text { o-NO }\end{array}$ \\
\hline 3 & 25 & 60 \\
\hline 5 & 85 & 90 \\
\hline 7 & 80 & 85 \\
\hline
\end{tabular}

Egypt. J. Chem. 54, No.1 (2011) 
Weight of the catalyst

In this series of experiments, different quantities of the catalyst were used for the reduction of $0.4 \mathrm{~g}$ of nitrophenol at $\mathrm{pH} 9$ and temperature of $70^{\circ} \mathrm{C}$. The time required for complete reduction for each experiment is given, Table (4). Under the previous conditions, the reduction reaction does not start using less than 0.05 $\mathrm{g}$ of $5 \% \mathrm{Ni}$ on $\mathrm{TiO}_{2}(\mathrm{R})$. Increasing the quantity of the catalyst leads to remakable decrease of the time required for complete conversion of nitrophenols to the corresponding aminophenols.

TABLE 4. The effect of the amount of catalyst on the time required for complete conversion of $\mathrm{p}$ - and $\mathrm{o}-\mathrm{NO}_{2}$ phenol (weight of catalyst $0.1 \mathrm{~g}$, volume of the solution $100 \mathrm{ml}, 7^{\circ} \mathrm{C}$ and $\mathrm{pH} 9$ ).

\begin{tabular}{|c|c|c|}
\hline $\begin{array}{c}\text { Weight (g) } \\
\text { of catalyst }\end{array}$ & $\begin{array}{c}\text { Time (min) for } \\
\text { complete conversion } \\
\text { of p-nitrophenol }\end{array}$ & $\begin{array}{c}\text { Time (min) for } \\
\text { complete conversion } \\
\text { of o-nitrophenol }\end{array}$ \\
\hline 0.05 & 15 & 17 \\
\hline 0.08 & 10 & 15 \\
\hline 0.1 & 7 & 6 \\
\hline 0.12 & 5.5 & 5 \\
\hline 0.15 & 5 & 3.5 \\
\hline
\end{tabular}

Concentration of nitrophenols

The effect of the amount of nitrophenols was examined at constant catalyst concentration, temperature, $\mathrm{pH}$ and the volume of reaction mixture. It was found that the time required for complete reduction increases with increasing nitrophenol concentration.

The shortest time required for complete conversion was achieved when the amount of nitrophenols were $0.1 \mathrm{~g}$ at $75^{\circ} \mathrm{C}$ in the presence of $0.1 \mathrm{~g}$ of $5 \% \mathrm{TiO}_{2}$ (R). At these conditions, 2 and 3 min were enough for complete reduction of $\mathrm{p}$ and o-nitrophenols, respectively. The dependence of conversion on the amount of nitrophenols was illustrated in Table 5.

TABLE 5. The effect of the amount of nitrophenols on the time required for complete conversion of $\mathrm{p}$ - and $\mathrm{o}-\mathrm{NO}_{2}$ phenol (weight of catalyst $0.1 \mathrm{~g}$, volume of the solution $100 \mathrm{ml}, 70^{\circ} \mathrm{C}$ and $\mathrm{pH} 9$ ) .

\begin{tabular}{|c|c|c|}
\hline $\begin{array}{c}\text { Weights (g) of } \\
\text { nitrophenols }\end{array}$ & $\begin{array}{c}\text { Time for complete } \\
\text { conversion of } \\
\text { p-nitrophenol (min) }\end{array}$ & $\begin{array}{c}\text { Time for complete } \\
\text { conversion of } \\
\text { o-nitrophenol (min) }\end{array}$ \\
\hline 0.1 & 3 & 2 \\
\hline 0.4 & 7 & 6 \\
\hline 0.7 & 15 & 12 \\
\hline
\end{tabular}

Catalyst recovery

For carrying this series of experiments a quantity of the catalyst was employed in conversion of nitrophenols into aminophenols. After complete Egypt. J. Chem. 54, No.1 (2011) 
conversion, the catalyst was filtered out and another quantity of nitrophenol in ethanol was added to the catalyst and the reaction is preceded till complete conversion. The process was repeated several times with the same catalyst. In each experiment the time for complete conversion was recorded. The results of this series of experiments are listed in Table 6. From this table, it can be observed that $\mathrm{Ni} / \mathrm{TiO}_{2}$ showed high catalytic activity for 5 times of conversion, yielding $100 \%$ conversion in each time.

TABLE 6. The relation between the numbers of repetition of catalyst against the time required for complete conversion of $\mathrm{p}$ - and $\mathrm{o}-\mathrm{NO}_{2}$ phenol (weight of catalyst $0.3 \mathrm{~g}$, weight of nitrophenol $0.4 \mathrm{~g}$, volume of the solution $100 \mathrm{ml}$, $70^{\circ} \mathrm{C}$ and $\left.\mathbf{p H} 9\right)$.

\begin{tabular}{|c|c|c|}
\hline No. of experiments & $\begin{array}{c}\text { Time for complete } \\
\text { recovery of Ni/TiO } \\
\text { (rutile) } \\
\text { p-nitrophenol }\end{array}$ & $\begin{array}{c}\text { Time for complete } \\
\text { recovery of Ni/TiO } \\
\text { (rutile) } \\
\text { o-nitrophenol }\end{array}$ \\
\hline 1 & 2 & 1.5 \\
\hline 2 & 3 & 3 \\
\hline 3 & 5 & 4 \\
\hline 4 & 10 & 7 \\
\hline 5 & 15 & 12 \\
\hline
\end{tabular}

\section{Conclusion}

$\mathrm{Ni}$ ions supported on $\mathrm{TiO}_{2}$ are transferred into metallic nickel after reduction with hydrazine hydrate. The nickel clusters are uniformly dispersed on the surface of titania support and the average size is about $25 \mathrm{~nm}$. Catalytic conversion of nitrophenols into aminophenols was conducted in the presence of the prepared nano-nickel $\mathrm{TiO}_{2}$. The kinetics of reduction reaction using $\mathrm{TiO}_{2}$ in rutile and anatase forms against $\mathrm{Ni}-\mathrm{Y}$ zeolite catalyst was studied. The results indicate that nanonickel supported on $\mathrm{TiO}_{2}$ was more active than the nanonickel in zeolite. The rate constant of the reduction of p-nitrophenol is slightly higher than that of the o-nitrophenol in case of $\mathrm{Ni}-\mathrm{Y}$ zeolite. The rate constant of the reduction of o-nitrophenol is slightly higher than that of the p-nitrophenol in case of $\mathrm{Ni}-\mathrm{TiO}_{2}$. Both rutile and anatase show comparable rate constant values for the reduction of $\mathrm{p}$ - and $\mathrm{o}$ - nitrophenols. Optimization was proceeded by studying the effect of many factors on the conversion of nitrophenols. Increase of the temperature of the reduction reaction raises the percentage of conversion. Optimum conditions to convert nitrophenols are $\mathrm{pH}=9$ and reaction temperature between $70-80^{\circ} \mathrm{C}$ by using a $5 \% \mathrm{Ni}-\mathrm{TiO}_{2}$. The increase of weight of catalyst decreases the time consuming for complete conversion.

\section{References}

1. Marais, E. and Nyokong, T., Adsorption of 4-nitrophenol onto Amberlite IRA-900 modified with metallophthalocyanines. J. Hazard. Mater. 152, 293-301(2008). 
2. O'Connor, O.A. and Young, L.Y., Toxicity and anaerobic biodegradability of substituted phenols undermethanogenic conditions. Environ. Toxicol. Chem. 8, 853862 (1989).

3. Dieckmann, M.S. and Gray, K.A., A comparison of the degradation of 4 nitrophenol via direct and sensitized photocatalysis in $\mathrm{TiO}_{2}$ slurries. Water Res. 30, 1169-1183 (1996).

4. Bo, L.L., Zhang, Y.B., Quan, X. and Zhao, B., Microwave assisted catalytic oxidation of $p$-nitrophenol in aqueous solution using carbon-supported copper catalyst. J. Hazard. Mater. 153 , 1201-1206 (2008).

5. Oturan, M.A., Peiroten, J., Chartrin, P. and Acher, A.J., Complete destruction of $p$-nitrophenol in aqueous medium by electro-Fenton method. Environ. Sci. Technol. 34, 3474-3479 (2000).

6. Modirshahla, N., Behnajady, M.A. and Mohammadi-Aghdam, S., Investigation of the effect of different electrodes and their connections on the removal efficiency of 4nitrophenol from aqueous solution by electrocoagulation. J. Hazard. Mater. 154, 778786 (2008).

7. Ca nizares, P., Suez, C., Lobato, J. and Rodrigo, M.A., Electrochemical treatment of 4- nitrophenol-containing aqueous wastes using boron-doped diamond anodes. Ind. Eng. Chem. Res. 43, 1944-1951 (2004).

8. Du, Y., Chen, H., Chen, R. and Xu, N., Synthesis of $p$-aminophenol from $p$ nitrophenol over nano-sized nickel catalysts. Appl. Catal. A: Gen. 277, 259-264 (2004).

9. Vaidya, M.J. Kulkarni, S.M. and Chaudhari, R.V., Synthesis of $p$-aminophenol by catalytic hydrogenation of p-nitrophenol. Org. Process Res. Dev. 7, 202-208 (2003).

10. Yang-Chuang Chang and Dong-Hwang Chen, Catalytic reduction of 4-nitrophenol by magnetically recoverable Au nanocatalyst. Journal of Hazardous Materials, 165, 664-669 (2009).

11. Vaidya, M.J., Kulkami, S.M. and Chaudhari, R.V., Synthesis of $p$-aminophenol by catalytic hydrogenation of p-nitrophenol. Org. Process Res. Dev. 7, 202-208 (2003).

12. Chen, R.Z., Du, Y., Chen, C.L., Xing, W.H., Xu, N.P., Chen, C.X. and Zhang, Z.L., Comparative study on catalytic activity and stability of nano-sized nickel and Raney nickel. J. Chem. Ind. Eng. (China), 54, 704- 706 (2003).

13. Du, Y., Chen, H.L., Chen, R.Z. and Xu, N.P., Synthesis of $p$-aminophenol from $p$ nitrophenol over nano-sized nickel catalysts. Appl. Catal. A: Gen., 277, 259- 264 (2004).

14. Rautanen, P.A., Aittamaa, J.R. and Krause, A.O.I., Liquid phase hydrogenation of tetralin on $\mathrm{Ni} / \mathrm{Al}_{2} \mathrm{O}_{3}$. Chem. Eng. Sci. 56, 1247-1254 (2001).

15. Suh, D.J., Park, T.J., Lee, S.H. and Kim, K.L., Nickel-alumina composite aerogels as liquid-phase hydrogenation catalysts. J. Non-Cryst. Solids, 285, 309- 316 (2001).

Egypt. J. Chem. 54, No.1 (2011) 
16. Wu, W.H. and $\mathbf{X u}, \mathbf{J}$., Liquid-phase hydrodechlorination of chlorinated benzenes over active carbon supported nickel catalysts under mild conditions. Catal. Commun. 5, 591-595 (2004).

17. Wu, W.H., Xu, J. and Ohnishi, R., Complete hydrodechlorination of chlorobenzene and its derivatives over supported nickel catalysts under liquid phase conditions. Appl. Catal. B: Environ., 60, 129-137 (2005)

18. Kapoor, M.P. and Matsumura, Y., A comparative study of liquid- and gas-phase methanol decomposition catalyzed over nickel supported on silica. J. Mol. Catal. A: Chem. 178, 169-172 (2002).

19. Toppinen, S., Rantakyh, T.K., Salmi, T. and Aittamaa, J., The liquid phase hydrogenation of benzene and substi- tuted alkylbenzenes over a nickel catalyst in a semi-batch reactor. Catal. Today, 38, 23-30 (1997).

20. Quincoces, C.E. and Gonzfilez, M.G., Kinetic study on Coz refroming of methane. Chin. J. Chem. Eng. 9, 190- 195 (2001).

21. Hadjiivanov, K., Mihaylov,M., Abadjieva, N. and Klissurski, D., Characterization of Ni-TiO? catalysts prepared by successive adsorption-reduction of $\mathrm{Ni}^{2+}$ ions. $J$. Chem. Soc. Faraday Trans. 94, 3711-3716 (1998).

22. A.J., Geus, J.W., Metal-support interaction: titania- supported and silica-supported nickel catalysts. J. Catal. 170, 217-226 (1997).

23. Li, Y.Z., Xu, B.L., Fan, Y.N., Feng, N.Y., Qiu, A.D., Miao, J.W., He, J., Yang, H.P. and Chen, Y., The effect of titania polymorph on the strong metal-support interaction of $\mathrm{Pd} / \mathrm{TiO}_{2}$ catalysts and their application in the liquid phase selective hydrogenation of long chain alkadienes. J. Mol. Catal. A: Chem. 216, 107-114 (2004).

24. Chen Rizhi, Yan, D.U. Xing Weihong and Nanping, X.U., The effect of titania structure on $\mathrm{Ni} / \mathrm{TiO}_{2}$ catalysts for p-nitrophenol hydrogenation. Chinese J. Chem. Eng. 14 (5), 665-669 (2006).

25. Max Lauwiner, Paul Rys and Joerg Wissmann, Reduction of aromatic nitro compounds with hydrazine hydrate in the presence of an iron oxide hydroxide catalyst. I. The reduction of monosubstituted nitrobenzenes with hydrazine hydrate in the presence of ferrihydrite. Applied Catalysis A: General, 172, 141-148 (1998).

26. Ibrahim, Haiam H., El-Mekkawi, Doaa M., Hassan, S.A. and Selim, M.M., Innovative method for the reduction of nitrophenols using nickel nanocatalysts in zeolite-Y prepared from Egyptian kaolin. Egypt. J. Chem. 53 (4), 1-14 (2010).

27. Selim, M.M., Abd El Maksod, I.H. and Saleh, T.S., The use of nano supported nickel catalyst in reduction of p-nitrophenol using hydrazine hydrate as hydrogen donor. Egypt. J. Chem. 52 (4), 491-506 (2009). 


\section{دراسـة مقارنـة في تـأثير الحامل على حفـاز النيكل النـانومتري في اختزال النيتروفينولات}

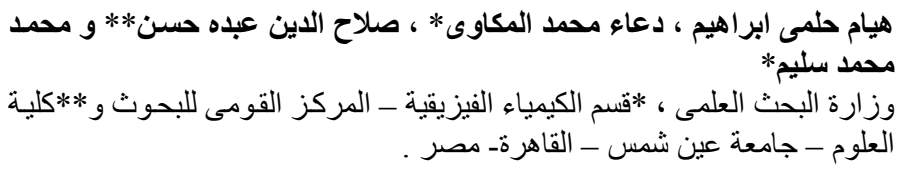

النامومتري فى هذا البحث تم عمل اختز ال حفزي للبار او الأرثو نيتروفينو لات إلى

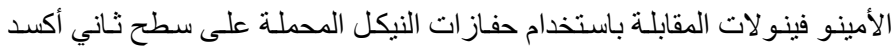

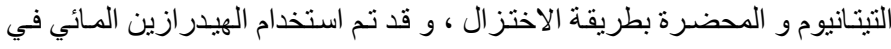

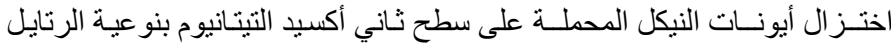

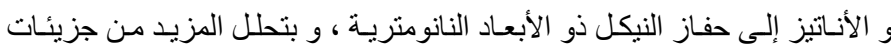

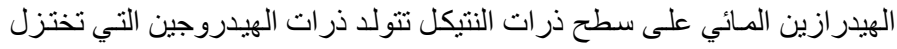
بفاعلية مجمو عات النيترو ، و قد تم استخدام العديد من التقنيات مثل حيود الأشعة لتونة السينية و الأشـعة تحت الحمـر اءو و الميكروسكوب الإلكترونسي الانتقالي، و جهاز

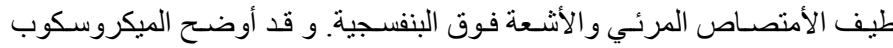

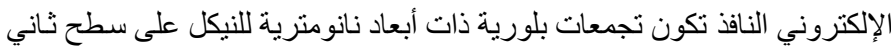

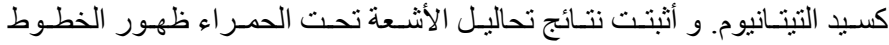

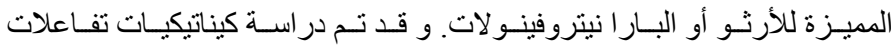

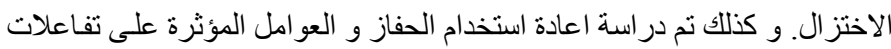
الاختز ال مثل تركيـز الفينول، الأس الهيدروجيني، كميـة الحفاز و درجـة الحرارة.

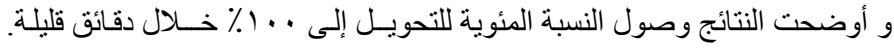
و تثير النتائج إلى أن النيكل النامومتري المحمل على سطح ثناني أكسيد التيتانيوم

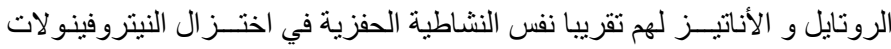

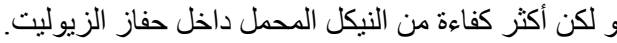

